THE SCIENTIFIC ACTIVITY OF THE FACULTY OF LAW AT THE UNIVERSITY OF BIAŁYSTOK ASSOCIATED WITH THE COUNTRIES OF CENTRAL AND EASTERN EUROPE

Among scientific activity connected with the research conducted by Faculty of Law at the University of Bialystok in 2016-2017 the following publications, lectures and participation in international projects can be mentioned:

\section{SCIENTIFIC ACTIVITY:}

- Conference "From Theory to Practice in Language for Specific Purpose" organized by Association of LSP Teachers at Higher Education Institutions, 19-20.02.2016, Croatia.

Conference participants:

- dr Halina Sierocka "Prospects of teaching English for legal purposes at tertiary level in Poland".

- Conference "Creation and application of law as a factor in the development of modern economic systems" organized by Janka Kupala Grodno State University, 16-17.03.2016, Belarus.

Conference participants:

- dr hab. Katarzyna Laskowska, prof. UwB "Illegal trade in tobacco products as a threat to the Polish economy";
- dr hab. Sławomir Presnarowicz, "Amendments to the law in appealing tax decisions to administrative courts in Poland".

- Conference "National minorities - an opportunity, a challenge or a threat to national security?" organized by Association of Polish Scholars of Lithuania, 28-30.04.2016, Lithuania.

Conference session chairman: dr hab. Mieczysława Zdanowicz, prof. UwB.

- Conference "XXII Annual Forum of Young Legal Historians" organized by University of Belgrade, 5-9.05.2016, Serbia.

Conference participants:

- dr Marcin Łysko "Legislative procedures in Poland in 20th century".

- Conference "Spreading Standards, Building Capacities: European Administrative Space in Progress" organized by Network of Institutes and Schools of Public Administration in Central and Eastern Europe, University of Zagreb, 18-22.05.2016, Croatia. Conference participants:

- dr Anna Budnik "When the government says "no". The privacy right as an exemption from freedom of information in Poland". 
- Conference "Gouvernance financière locale" organized by Hubei University of Economics and FONDAFIP (Association for the International Foundation of Public Finance), 25-31.05.2016, China.

Conference participants:

- dr Urszula Zawadzka-Pąk "Subventions and vertical transfers in Poland".

- Conference "The response of the Visegrad 4 Countries to the Migration Crisis" organized by Hungarian Europe Society, 29-31.05.2016, Hungary.

Conference participants:

- dr hab. Elżbieta Kużelewska "Poland towards Migration Crisis".

- Conference "About Public Governance, Administration and Finances Law review" organized by Széchenyi István University in Győr, 1-2.06.2016, Hungary.

Conference participants:

- dr hab. Mariusz Popławski, prof. UwB “The Assumptions of a New Tax Ordinance in Poland";

- dr Artur Modrzejewski

- dr Marcin Tyniewicki

- XV International Scientific Conference "Concepts of Tax Codes. The Fifteenth Anniversary of the Center's Activity" organized by The Faculty of Law, University in Bialystok, 25-27.09.2016, Poland.

Conference participants:

- prof. zw. dr hab. Eugeniusz Ruśkowski - presentation of the Center Scientific Bulletin;

- dr hab. Mariusz Popławski, prof. UwB - "Polish Tax Code";

- dr Urszula Zawadzka-Pąk, dr Rafał Dowgier - "Scientific publications as an element of evaluation of scientific output in Poland";

- prof. zw. dr hab. Leonard Etel; prof. zw. dr hab. Joanna Salachna; dr hab. Janusz Stankiewicz, prof. UwB; dr hab. Sławomir Presnarowicz; dr Paweł Lewkowicz; dr Marcin Tyniewicki; dr Grzegorz Liszewski; mgr Ewa Lotko.
- Conference "Concept of a tax code - introducing the Polish tax codification and trends in the Hungarian tax administration" organized by National University of Public Service, 7.10.2016, Hungary.

Conference participants:

- prof. zw. dr hab. Leonard Etel "Do we need a new tax code in Poland?";

- dr hab. Mariusz Popławski, prof. UwB “Tax procedures in the new Polish tax code";

- dr hab. Rafał Dowgier "Basic principles of taxation and tax procedure and the rights and obligation of taxpayers";

- dr Piotr Pietrasz "Constitutional aspects of the tax code in Poland".

- Conference "Vilnius Arbitration Day" organized by the Court of Commercial Arbitration, 6-8.10.2016, Lithuania.

Conference participants: dr Marta Skrodzka.

- According to the cooperation with Scientific and Research Institute of Financial and Tax Law in Almaty (Kazakhstan) and active participation in VII International Scientific and Theoretical Conference organized by Institute of Financial and Tax Law in Almaty "Current problems of legal administration regulation in public finances", 20.10.2016, prof. zw. dr hab. Eugeniusz Ruśkowski, received William Petty Medal. The prize is awarded in recognition of his activities in the field of comparative research. During the conference prof. zw. dr hab. Eugeniusz Ruśkowski had a lecture on "Current problems of legal administration regulation in public finances".

- Ceremonial inauguration of the School of German Law and the opening of the German-Belarusian-Polish Seminar, organized as part of the School of German Law conducted in cooperation with the Law Faculty of the Humboldt-Universität zu Berlin and Janka Kupala Grodno State University, 27.10.2016, Poland.

- International Seminar "Le procedure giudiziali nella Roma antica e nell'attualita tra gli interessi pubblici e private" (“The legal procedure in ancient 
Rome and current public and private interests") organized by Universita di Econamia Nazionalee Nondiale, Bratislava, 2-6.11.2016, Slovakia.

Conference participants:

- dr Piotr Kołodko "The role of quaestor as a prosecutor in criminal proceedings in the ancient Rome";

- prof. dr hab. Piotr Niczyporuk "La capacita giuridica e la tutela del nascituro nel diritto romano".

- Conference "The Issues of Tax Law Codification in Russia and Poland: the needs and necessity" organized by Russian Presidential Academy of National Economy and Public Administration, 10.11.2016, Russia.

Conference participants:

- prof. zw. dr hab. Leonard Etel "The new tax code";

- dr hab. Sławomir Presnarowicz "The principle in dubio pro tributario in the tax law in Poland".

- Conference "Stability and progressive development of legal systems in the context of integration processes" organized by Janka Kupala Grodno State University, 15-17.02.2017, Belarus.

Conference participants:

- dr hab. Katarzyna Laskowska, prof. UwB "Car theft in Polish Criminal Code";

- dr hab. Sławomir Presnarowicz "In dubio pro tributario in tax legislation"

- dr Jarosław Matwiejuk "Evolution of the judiciary in the Russian Federation".

- Dr Anna Budnik and dr Izabela Kraśnicka took part in meeting which was a part of the project "Introducing modules on law and rights in programmes of teacher training and educational sciences: a contribution to building rights - based education systems in countries in transition (ELA)" organized by Moscow City University, 3-5.02.2017, Russia.

- III международная научно-практическая конференция “Уголовная политика Республики
Белорусь: состояние и пути совершенствования" (III International Scientific and Practical Conference "Criminal policy of the Republic of Belarus: state and ways of improving") organized by Baranovichi State University, Baranavichy, 1013.05.2017, Belarus. Conference participants:

- dr hab. Katarzyna Laskowska, prof. UwB - "Наказания связанные с изоляцией осужденного от общества в свете уголовного кодекса 1997 г. и судебной практики в Польше".

- "Stability and Progressive Development of Legal Systems in the Context of Integration Process" organized by Janka Kupala Grodno State University, Grodno,15-17.03.2017, Belarus.

Conference participants:

- dr hab. Katarzyna Laskowska, prof. UwB “Car theft in Polish Criminal Code";

- dr hab. Ewa Czech, prof. UwB "Leasing agreement as nominate contract";

- dr hab. Sławomir Presnarowicz "In dubio pro tributario";

- dr Jarosław Matwiejuk "Evolution of the judiciary in the Russian Federation".

- Conference "Protecting Democracy. Law, Politics, Economy and Society in Central and Eastern Europe” organized by Széchenyi István University, Győr, 20-25.02.2017, Hungary.

Conference participants:

- dr Anna Budnik "Dostęp do sądu w Polsce"

- “Third International Scientific Conference - Civic Education and Practices of Democracy in Post-Soviet Countries" organized by Ivane Javakhishvili Tbilisi State University, Tbilisi, 29.06-6.07.2017, Georgia. Conference participants:

- dr hab. Elżbieta Kużelewska - "E-tools of Civic Participation in Poland. Perspectives for the Future".

- "III International Round Table Criminal Law: traditions and innovations dedicated to the scientist W.W. Staszis", Academy of State Penitentiary Service, Chernihiv, 06 - 08.09.2017, Ukraine. 
Conference participants:

- prof. dr hab. Katarzyna Laskowska - "Current problems in the establishment and execution of imprisonment in Poland"

- XVI International Scientific Conference “The Optimization of Organization and Legal Solutions of Public Revenues and Expenditures in Social Interest"), Faculty of Economics-Informatics Branch of the University of Bialystok in Vilnius, 20 - 22.09.2017, Lithuania.

Conference participants:

- prof. zw. dr hab. Eugeniusz Ruśkowski - introductory speech;

- dr hab. Sławomir Presnarowicz, prof. UwB - "The concept of public interest in the application of reliefs in the payment of tax liabilities on selected examples of judgments of Polish administrative courts"

- dr Urszula Zawadzka-Pąk - "From multidimensional model of accountability for public debt to the model of legal norms effective in limiting public debt. Theoretical approach";

- dr Krzysztof Teszner - "The national fiscal administration - challenges and expectations";

- dr Pawel Lewkowicz - "Public interest and the social interest in the polish law system"

- dr Ewa Lotko - "Tax motivation as an instrument protecting public financial interest";

- prof. zw. dr hab. Leonard Etel; dr hab. Mieczysława Zdanowicz, prof. UwB; dr hab. Rafał Dowgier; dr Grzegorz Liszewski.

- International Scientific-Practical Conference "Legal and comparative analysis of commercial and civil law in Poland and Lithuania", Association of Polish Lawyers in Lithuania, Vilnius, 2930.09.2017, Lithuania.

Conference participants:

- dr hab. Katarzyna Bagan-Kurluta, prof. UwB - "Motherhood in the comparative aspect";

- dr Urszula Drozdowska - "Alternative dispute resolution in medical matters".
- "XIII Luby Law Days - International Scientific Conference Social Function of Law and Growing Wealth Inequality", Faculty of Law, Trnava University, Smolenice, 27.09. - 01.10.2017, Hungary.

Conference participants:

- dr hab. Piotr Fiedorczyk - "Matrimonial property regimes and their impact on the economic situation of families. Historical issues".

- International Scientific-Practical Conference "Legal and comparative analysis of commercial and civil law in Poland and Lithuania", Association of Polish Lawyers in Lithuania, Vilnius, 2930.09.2017, Lithuania.

Conference participants:

- dr Arkadiusz Bieliński - "Problems of the costs of mediation proceedings in civil proceedings in Poland".

- International Scientific and Practical Conference "Corporate Law of Ukraine and European Countries: Issues of Theory and Practice", Vasyl Stefanyk Precarpathian National University, Ivano-Frankivsk, 5 - 8.10.2017, Ukraine.

Conference participants:

- dr Renata Tanajewska - " Management and supervision in commercial companies in Poland - selected issues".

- Міжнародна науково-практична конференція «Кримінально-правове забезпечення сталого розвитку України в умовах глобалізації (International scientific and practical conference “Criminal law protection of Ukraine's continuing development in the conditions of globalization") organized by Yaroslav the Wise State University of Law, Kharkiv, 12-13.10.2017, Ukraine.

Conference participants:

- prof. dr hab. Katarzyna Laskowska - "Electronic supervision system as a way of executing the penalty of deprivation of liberty in Poland".

- V International Scientific and Practical Conference "Penal Policy and Practice of the Application 
of Law", organized by the Russian State University of Justice, Saint Petersburg, 3.11.2017, Russia.

Conference participants:

- prof. dr hab. Katarzyna Laskowska - "The dimension of penalties against perpetrators of crimes in Poland in the years 1999-2016".

- Day Law, Faculty of Law, Masaryk University, 8-11.11.2017, the Czech Republic.

Conference participants:

- dr Ewa Lotko - "The negative determinants of the taxpayers' fiscal motivation";

- dr Urszula Zawadzka-Pąk - "Participatory Budgeting under the Pressure of Fiscal Austerity in three Polish Cities".

- International Scientific Conference "Modernisation of Company Law: Effective, Innovative and Optimal Solutions", Vilnius University, 1619.11.2017, Lithuania.

Conference participants: dr Renata Tanajewska.

\section{RESEARCH AND TEACHING ACTIVITIES ABROAD AND ERASMUS+:}

- dr hab. Sławomir Presnarowicz, lectures "Administrative courts in Poland", Erasmus+ Program, Voronezh State University, Russia (3-8.04.2016);

- dr hab. Katarzyna Laskowska, prof. UwB, scientific internship in A. I. Herzen Russian State University, Russia (3-17.04.2016);

- dr hab. Mariusz Popławski, prof. UwB, lectures "General tax law and substantive tax law", Erasmus+ Program, Masaryk University, Brno, the Czech Republic (19-25.06.2016);

- dr Lech Jamróz, lectures “The Constitutional Tribunal in Poland on the background of constitutional judicature", Erasmus+ Program, University of Latvia, Latvia (17-21.10.2016);

- dr Anna Budnik, lecture "Mediation in court-administrative proceedings in Poland", Erasmus + Program, Turiba University, Latvia (1217.03.2017);
- dr hab. Piotr Fiedorczyk, Erasmus+ KA107 lectures, University of Latvia, lectures for Ph.D. students, Latvia (14-27.04.2017);

- dr hab. Katarzyna Laskowska, prof. UwB, Erasmus+ KA107 lectures, Janka Kupala Grodno State University Faculty of Law, Grodno, Belarus (1420.05.2017);

- dr hab. Katarzyna Laskowska, prof. UwB, lecture "Crime Trends and Prevention of Criminality in Poland”, Erasmus+ KA107 Program, Janka Kupala Grodno State University, Grodno, Belarus (15-19.05.2017);

- dr Wioleta Hryniewicka-Filipkowska - internship abroad as a part of an international project Law and Rights Modules in Teacher Training Programmes, Erasmus+ Program, supervisor: Prof. Gracienne Lauwers (Vrije Universiteit Brussel), Kaunas, Lithuania (4-10.06.2017);

- dr hab. Mieczysława Zdanowicz, prof. UwB, lecture "Practical aspects of the functioning of the European Citizens' Initiative”, Erasmus+ Program, Immanuel Kant Baltic Federal University, Kaliningrad, Russia (10-17.09.2017);

- dr hab. Anna Doliwa-Klepacka, lecture "Democratization of legislative procedures in the European Union", Erasmus+ Program, Immanuel Kant Baltic Federal University, Kaliningrad, Russia (1017.09.2017);

- dr hab. Katarzyna Bagan-Kurluta, prof. UwB, Erasmus + Program training course, Masaryk University, Brno, the Czech Republic (16-23.09.2017);

- dr Halina Sierocka, lecture "How to stimulate oral statements during legal English classes?", Erasmus+ Program, Masaryk University/Language Centre, Brno, the Czech Republic (17-22.09.2017);

- dr Halina Sierocka - courses raising professional qualifications, Masaryk University, Brno, the Czech Republic (23 - 24.09.2017);

- dr hab. Anna Piszcz, prof. UwB, participation in the doctoral committee, Mykolas Romeris University, Vilnius, Lithuania (5-7.01.2017). 